\title{
TINJAUAN HINDU TERHADAP TELAAH OLEH SIGMUND FREUD (1856- 1939) “AGAMA SEBAGAI OEDIPUS COMPLEX”
}

\author{
Krisna S. Yogiswari \\ STAH Negeri Mpu Kuturan Singaraja
}

\begin{abstract}
Abstrak
Sigmund Freud dalam teori psikoanalisa agamanya menyatakan bahwa agama sebagai Oedipus complex . Pandangan Freud ini menurunkan derajat agama dan martabat penganutnya. Agama Hindu dalam praktik peribadatan sehari-hari (persembahyangan) banyak menggunakan ritual-ritual, simbol dan korban suci (totem dalam terminologi Freud), juga banyak didasarkan pada etika atau aturan-aturan (taboo), dengan tujuan untuk menyelaraskan antara yang profan dengan yang sakral. Kajian ini merupakan penelitian kualitatif kajian tokoh historikal-faktual, dengan menggunakan metode hermeutika untuk mengkaji psikoanalisa agama khususnya agama sebagai oedipus complex menurut Sigmund Freud sebagai objek formal dan ajaran Hindu khusunya telaah atas Bhagavadgita sebagai objek formal. Agama Hindu sebagai agama yang terbuka dan universal berusaha meninjau dan menjawab sesuatu dengan sebuah apologi (pembenaran agama dengan dogma-dogma inklusif), dimana agama Hindu menjawab segala tantangan terhadap teologinya dengan pernyataan dan argumentasi yang logis-ilmiah yang bersandar pada pengetahuan yang ilmiah dan ajaran Veda.
\end{abstract}

\section{Kata Kunci: Psikoanalisa Agama, Oedipus Complex, Hindu}

\section{PENDAHULUAN}

Sigmund Freud (1856-1939) adalah salah satu orang yang dengan tegas menolak keberadaan agama dengan mengambil sikap menjadi seorang ateis. Freud merupakan seorang psikolog yang sangat terkenal di dunia, dan dapat dikatakan sebagai bapak psikoanalisa (Suseno, 2006: 84). Freud sendiri tidak pernah mencoba membuktikan keberadaan Tuhan. Bagi Freud ritual-ritual keagamaan hanyalah sebuah refleksi dari ketakutan manusia akan dosa masa lalu.

Ritual-ritual, kepercayaan, dan aturan-aturan agama bagi Freud muncul dari Oedipus complex. Pals (2011: 94) menjelaskan bahwa istilah Oedipus complex muncul dalam sebuah tragedi terkenal (yang diterjemahkan oleh Freud) dari karangan Sophocles Kisah ini menceritakan tentang Oedipus, yang tanpa sadar telah membunuh ayahnya dan menikahi ibunya. Menyadari kematian sang ayah, maka anaknya pun merasa bersalah dan membuatkan ritual-ritual persembahan berupa simbol-simbol (tottem) sebagai pengganti ayahnya, dan mulai saat itu bersumpah bahwa menikahi orang tua adalah taboo (terlarang). Analisa psikologi Freud terhadap kisah tersebut, bahwa agama tiada lain merupakan pelampiasan dari emosi-emosi manusia.

Analisis Freud tentu dapat dibantah, tetapi tidak sepenuhnya dapat dianggap salah. Freud tampkanya benar dalam beberapa hal, bahwa fenomenanya saat ini banyak orang 
yang beragama setelah melakukan berbagai macam dosa dan dengan mudah melakukan ritual-ritual penebusan dosa (totem). Dewasa ini masih banyak terjadi pernikahan sedarah, atau yang lebih parah adalah pemerkosaan

Analisis Freud tentu dapat dibantah, tetapi tidak sepenuhnya dapat dianggap salah. Freud tampaknya benar dalam beberapa hal, bahwa fenomenanya saat ini banyak orang yang beragama setelah melakukan berbagai macam dosa dan dengan mudah melakukan ritual-ritual penebusan dosa (totem). Di masa kini, masih banyak terjadi pernikahan sedarah, atau yang lebih parah adalah pemerkosaan yang dilakukan oleh orang tua (baik kandung maupun tiri) yang dilakukan terhadap anaknya. Peristiwa ini akhirnya menimbulkan penyesalan, sehingga timbullah niat untuk bertobat, dan beberapa agama mengakomodasi hal ini. Banyak juga orang beragama seperti anak-anak (infantil), apabila doanya terkabul maka akan senang dan bahagia hatinya, sebaliknya apabila tidak terpenuhi keinginannya maka akan menghujat dan marah, lalu mempertanyakan keadilan Tuhan. Demikian juga, orang-orang kelainan mental dalam beragama (neurosis), fenomena di masyarakat banyak terdapat orang yang mengaku-ngaku Tuhan, (kadewan-dewan), atau mengaku sebagai nabi, avatara dan sebagainya.

Bertitik tolak dari permasalahan tersebut maka peneliti ingin melakukan analisis terhadap psikoanalisa agama oleh Freud, khususnya dari pandangan Hindu. Hindu adalah ajaran 81 mengenai pengetahuan ketuhanan Hindu yang berlandaskan pada kebenaran Veda. Donder (2006: 4) menjelaskan bahwa ajaran Hindu disebut sebagai Brahmavidya, yaitu pengetahuan tentang Brahman (Tuhan yang abadi). Brahmavidya bersandar pada dua macam pengetahuan, paravidya adalah pengetahuan yang lebih tinggi (pengetahuan langsung kepada Brahman), dan aparavidya adalah pengetahuan yang lebih rendah (profan) yang bersifat duniawi.

Banyak masyarakat dalam mengimplementasikan yang belum mengetahui dan memahami nilai tattvanya, sehingga yang berlaku adalah gugon tuwon (mula keto), serta bersifat ayawera (rahasia). Hal ini, akan menimbulkan banyak pertanyaan dalam masyarakat Hindu khususnya (timbul kesenjangan), dan bagi masyarakat luar (umat agam a lain) pada umumnya. Dengan demikian, dapat menimbulkan persepsi atau justifikasi bahwa analisis Sigmund Freud tentang agama adalah benar adanya. Pemahaman ini apabila dibiarkan berlarut-larut (tanpa bantahan, sanggahan atau pun jawaban yang memadai) akan menimbulkan kegelisahan pada umat beragama, bahkan yang lebih parah "mungkin" umat akan berbalik menjadi pengikut Freud.

\section{PEMBAHASAN}

Analisis psikoanalisa Sigmund Freud terhadap agama dimulai dari pemikirannya yang kritis dalam menanggapi permasalahan sosial khususnya agama. Freud secara gamblang memang selalu memperlihatkan kerasionalannya dalam menganalisa permasalahan yang 
menyangkut agama. Analisanya yang selalu bertumpu pada rasionalitas membawa orang-orang terhanyut pada alur pemikirannya yang revolusioner. Freud menganalisa agama dari segi keilmuannya, dan berusaha keluar dari keyakinan pribadinya. Dalam hal ini sifat keobjektifannya terkadang menimbulkan persoalan-persoalan, karena bertabrakan dengan nilai-nilai atau kepercayaan masyarakat yang dianggap suci. Dengan demikian, untuk memahami ajaran psikoanalisa agama Freud tidak dapat dilihat secara sepenggal-pengal, melainkan harus dilihat secara utuh. Freud sesungguhnya menganalisis agama bukan dalam tataran esensi, tetapi lebih kepada lapisan kulit luar yang diperlihatkan oleh agama. Di mana dalam tataran ini (luar), tidak dapat dipungkiri sering menimbulkan perbedaan tafsir.

Persoalan agama yang dibicarakan oleh Freud pada tataran cara atau bagian luarnya, misalnya mengenai tatanan praktik beragama yang dianggapnya cenderung mengarah pada sifat-sifat yang kurang masuk akal dan mengarah pada kesia-siaan. Umat beragama diaggapnya beragama karena adanya ketakutan, bukan karena kecintaan pada Tuhan. Di mana agama yang semulanya dibentuk untuk mendamaikan malah berbanding terbalik menyengsarakan umat. Seperti misalnya, umat beragama berlomba-lomba melaksanakan upacara yang besar tanpa mempertimbangkan kemampuan, sedangkan agama telah memberi keleluasaan untuk memilih jalan yang lebih mudah. Dalam kondisi ini, argumen Freud dapat dibenarkan. Namun demikian, di sisi lain generalisasi atau penyetaraan kesalahan bagi umat beragama yang melaksanakan tradisi dan ritual tersebut tidaklah sepenuhnya benar. Di mana pada hakikatnya agama mengajarkan nilai-nilai kebenaran, sehingga manusia bisa menatanya ke arah yang lebih baik dan benar.

Berdasarkan hal tersebut, maka kritik Freud terhadap agama, yang ditinjau dari ajaran psikoanalisanya dapat dibagi menjadi tiga sub bagian, yakni: agama sebagai oedipus complex (totem dan tabu), agama sebagai ilusi kekanak-kanakan (infantil), dan agama sebagai gangguan neurosis. Ketiga hal ini merupakan pokok permasalahan dalam analisa psikoanalisa agama Freud, di mana dirinya menegaskan bahwa agama muncul sebagai kelemahan dari kepribadian manusia, atau sebatas bentuk dari ketertekanan psikologis manusia, yang pada akhirnya memunculkan ilusi-ilusi bawah sadar. Penelitian ini memfokuskan pada pandangan psikoanalisa Freud tentang agama sebagai oedipus complex.

\subsection{Psikoanalisa Agama Sigmund Freud "Agama Sebagai Oedipus complex"}

Freud merupakan psikolog yang menganalisa cara dan tradisi umat beragama. Salah satu psikoanalisa Freud menyatakan bahwa orang-orang beragama mengidap kelainan jiwa "oedipus complex". Pada hakikatnya kata oedipus complex memiliki arti keadaan terfiksasi dalam fase Oedipal dari perkembangan emosional, yakni ketika seorang anak lelaki jatuh cinta pada ibunya, dan anak perempuan jatuh cinta pada ayahnya (semenjak masa Freud situasi yang terakhir 
digambarkan sebagai Electra Complex). Dalam kasus gangguan jiwa ini penderita oedipus complex merasakan sensasi hasrat pada orang dari jenis kelamin berbeda, pada waktu bersamaan merasakan perasaanperasaan benci pada orangtua dari jenis kelamin yang sama. Keduanya mengarah pada perasaan-perasaan bersalah yang sangat kuat tetapi tidak diakui, dan kecenderungan untuk menghukum diri sendiri yang dapat diekspresikan dalam berbagai bentuk. Perkembangan emosional individu bersangkutan terhalang. Penderita mungkin saja tidak menikah, atau jika menikah perkawinannya tidak bahagia, karena sebagian besar energinya dicurahkan untuk bertarung melawan hasrat Oedipal yang tak disadarinya. Penderita oedipus complex juga tidak dapat dewasa secara sempurna dan kebahagiannya terkoyak. Dengan alasan tersebut Freud melihat oedipus complex sebagai salah satu penyebab utama penyakit jiwa. Dalam perkembangannya beberapa ahli ada yang tidak setuju dengannya, namun banyak para ahli psikiatri yang mengikuti pandangannya (Baker, 2007: 177).

Persoalan agama yang dibicarakan oleh Freud pada tataran cara atau bagian luarnya, misalnya mengenai tatanan praktik beragama yang dianggapnya cenderung mengarah pada sifat-sifat yang kurang masuk akal dan mengarah pada kesia-siaan. Umat beragama diaggapnya beragama karena adanya ketakutan, bukan karena kecintaan pada Tuhan. Di mana agama yang semulanya dibentuk untuk mendamaikan malah berbanding terbalik menyengsarakan umat. Seperti misalnya, umat beragama berlomba-lomba melaksanakan upacara yang besar tanpa mempertimbangkan kemampuan, sedangkan agama telah memberi keleluasaan untuk memilih jalan yang lebih mudah. Dalam kondisi ini, argumen Freud dapat dibenarkan. Namun demikian, di sisi lain generalisasi atau penyetaraan kesalahan bagi umat beragama yang melaksanakan tradisi dan ritual tersebut tidaklah sepenuhnya benar. Di mana pada hakikatnya agama mengajarkan nilai-nilai kebenaran, sehingga manusia bisa menatanya ke arah yang lebih baik dan benar.

Transendensi konsepsi mitologis dunia bagi Freud merupakan sebuah transendensi dari aktivitas mental tak sadar, yang berada di luar sains. Hal ini bertugas mengubah realitas transenden ke dalam sebuah psikologi tak sadar, yang selanjutnya mengubah metafisika menjadi metapsikologi. Dengan ini, berlanjut pada sejarah umat manusia awal yang pada akhirnya menjadi pusat ketertarikan Freud. Realitasnya saat ini, dapat ditinjau dari dua fenomena yang dilihatnya aktif dalam kebudayaan masa kini, di mana dalam karyanya Tottem und Taboo (Totem dan Tabu) Freud mencari penjelasan dalam sejarah umat manusia sejak awal. Pertama, dibuktikan dengan adanya fakta aneh bahwa anggota peradaban saat ini menerima ajaran etik, seperti kategori imperatif dari Kant yang dapat bekerja dalam sebuah bentuk kewajiban dan ketika semua motivasi sadar ditolak. Kedua, adalah perasaan bersalah yang amat besar yang dapat ditemui pada setiap orang, terlepas dari sejarah kehidupan perseorangan dan jelas-jelas sebagai bagian dari eksistensi manusia; 
dan hal ini membingungkan Freud (Scharfenberg, 2003: 221).

Freud kemudian berusaha keras menunjukkan bahwa ketentuanketentuan tabu dari masyarakat primitif yang menunjukkan struktur sama sebagai sebuah kategori imperatif (bentuk-bentuk perintah). Penafsiran Freud atas tabu sebagai hasil dari konflik ambivalensi, bisa meyakinkan para psikoanalisis yang paling skeptis sekalipun, tetapi Freud dipersilahkan dalam merekontruksi sosok ayah, yang digambarkarkan sebagai tokoh utama yang kuat dari teori totemnya (Scharfenberg, 2003: 222-223). Freud dalam hal ini, menyatakan bahwa salah satu dari teka-teki utama agama totem bisa dijelaskan dengan cara mengetahui sebab dari; mengapa jenis binatang tertentu dianggap suci oleh suku tertentu dalam masyarakat primitif, yang mendapatkan penghormatan tertinggi, namun disembelih sekali setahun dan dimakan oleh anggotaanggota pemujaan dalam sebuah jamuan makan yang khidmat. Dengan demikian, bagi Freud tidak ada lagi keraguan bahwa binatang totem hendak ditafsirkan sebagai sebuah pengganti perantara dari ayah, dan sungguh merupakan pengganti seorang ayah yang utama, kuat dan purba. Freud juga mengatakan bahwa agama totem muncul dari kesadaran rasa bersalah dari para putra sebagai usaha untuk meredakan perasaan pertobatan dan mengambil hati sang ayah yang terlukai melalui ketaatan yang sudah terlambat dan menjadikannya sebuah kewajiban untuk memperbaharui kejahatan pembunuhan ayah dalam pengorbanan binatang totem tadi (Scharfenberg, 2003: 224).

Lebih lanjut Scharfenberg (2003: 224-225) menjelaskan bahwa; meskipun Freud yakin orang harus melawan godaan, untuk mengambil sesuatu yang rumit sebagai agama dari satu asal mula yang tunggal, namun Freud berkeras dalam generalisasi yang tidak dibenarkan. Agama terbukti mencari usaha-usaha untuk menyelesaikan masalah yang sama, yaitu memberikan jawaban atas rasa bersalah terhadap ayah yang pertama. Dengan cara totem dan tabu, Freud membangkitkan keberatan yang tajam dan penolakan keras. Freud secara mendasar merusak skema konseptual dari pandangan positifis logis, dengan mengalah pada pemikirannya dan ingin mengatasinya. Masalah pemikiran historis yang dipahami atas dasar mitos asal mula dan menegaskan prioritas temporal dimana Freud ingin memberikan otoritas pada sesuatu dan karenanya menjadikan masa lalu sebagai tuan bagi masa kini.

Penjelasan mengenai oedipus complex yang merujuk pada totem dan tabu dapat dijelaskan pula dari pernyataan berikut:

Keadaan gangguan psikis yang dialami Watugunung dengan keinginan mengawini ibunya dewi Sinta, merupakan suatu cerminan bagi semua orang. Sebab incest perkawinan sedarah merupakan hal yang tidak dibenarkan. Sebab akan berdampak pada gen anak yang akan lahir. Kemudian sikap Watugunung yang mengatakan diri sakti tidak akan dapat terkalahkan. Merupakan pesan moral yang harus dianalisa. Sebab sikap demikian 
mencerminkan sebuah kasus oedipus complex. Oleh sebab itu, dalam mitologi Watugunung, umat Hindu diajari untuk tetap ingat dan tidak takabur. Karena orang yang berilmu, namun sombong tidak akan mendapatkan kebahagiaan dalam hidupnya (Tary Puspa, wawancara 27 Juni 2020).

Penjelasan mengenai pemahaman oedipus complex dan totem serta tabu di tegaskan pula oleh Ramiati dengan pendapat sebagai berikut:

Keadaan anak yang orang tuanya menguasai kerajaan dan menguasai wanita-wanita namun memiliki sifat yang kejam, kemudian anak-anaknya bersatu untuk membunuh ayahnya dan menikahi ibunya, hingga menimbulkan rasa berdosa. Kemudian menimbulkan sublimasi antara persamaan manusia, binatang dengan Tuhan. Hingga menyebabkan adanya perasaan cinta dan benci yang ada pada si anak secara bersamaan. Totem lahir sebagai wujud penghormatannya. Jika itu sebagai bentuk penghormatan itu benar. Namun dalam bentuk upacara, binatang dipuja itu kurang tepat. Kemudian, ketika memakan salah satu hewan, dibenarkan karena merupakan wujud dari sebuah penghormatan. Tetapi ketika, binatang disembah sebagai pengganti ayahnya itu bukanlah hal yang bijaksana. Sebab konsep memuja hendaknya diarahkan pada Tuhan bukan pribadi ayahnya. Walaupun dengan alasan mengharapkan pengampunan atas dosa masa lalu yang pernah di lakukan pada ayahnya (Ramiati, wawancara 27 Juni 2020).

Berdasarkan pengertian di atas, dapat disimpulkan bahwa oedipus complex merupakan suatu keadaan merasakan sensasi hasrat pada orang dari jenis kelamin berbeda, pada waktu bersamaan merasakan perasaanperasaan benci pada orang tua dari jenis kelamin yang sama. Keduanya mengarah pada perasaan-perasaan bersalah yang sangat kuat tetapi tidak diakui, dan kecenderungan untuk menghukum diri sendiri yang dapat diekspresikan dalam berbagai bentuk. Dengan alasan, bahwa semua agama terbukti mencari usaha-usaha untuk menyelesaikan masalah yang sama, yaitu memberikan jawaban atas rasa bersalah terhadap ayah yang pertama. Dengan cara totem dan tabu, Freud membangkitkan keberatan yang tajam dan penolakan keras terhadap praktik agama. Namun demikian, generalisasi atau pemahaman parsial dari sebuah perspektif tentang agama, melalui praktik totem dan tabu ini tidak dapat diterima sebagai kebenaran yang utuh.

\subsection{Tinjauan Hindu Terhadap Pandangan Agama sebagai Oedipus complex Menurut Sigmund Freud}

Psikoanalisa agama dari Sigmund Freud sampai saat ini masih mengalami kontradiksi. Hal tersebut dibuktikan dengan adanya tanggapan melalui karya tulis ilmiah peneliti dari beberapa perguruan tinggi, baik dari jurusan yang mendalami psikologi maupun agama. Barakatu (2007: 153157) dalam karyanya yang berjudul Psikoanalisa Terhadap Pandangan Sigmund Freud: Agama dan Implikasinya terhadap Pendidikan menjelaskan bahwa, Freud menganggap agama hanya sebuah ilusi, penganutnya mengidap neurosis dan bersifat Infantil. Pandangan Freud sekaligus menyatakan 
bahwa agama adalah suatu yang sia-sia, tidak berguna, dan merusak perkembangan kepribadian manusia karena keyakinan beragama hanya merupakan proses sublimasi dari konflik yang terjadi pada masa kanakkanak antara orangtua dan anak yang disebutnya sebagai oedipus complex .

Psikoanalisa tentang agama yang dikemukakan oleh Freud juga secara tidak langsung menyentuh ranah ajaran Ketuhanan Hindu. Dibuktikan dengan analisis terhadap mitos Watugunung dan legenda Sangkuriang. Berdasar kisah tersebut dapat ditemukan adanya masalah oedipus complex (totem dan tabu) yang mengarah pada psikoseksual dan bertumpu pada incest. Dengan demikian, dalam penelitian ini akan diuraikan lebih lanjut mengenai psikoanalisa agama Freud, yakni oedipus complex .

S. Reinach menguraikan dalam bukunya Code du Tottemisme bahwa ada dua belas macam tulisan semacam katekismus (kitab pelajaran agama Kristen yang umumnya berisikan tentang tanya jawab) mengenai agama totem, yaitu:

1. Binatang-binatang tertentu tidak boleh dibunuh atau dimakan, melainkan manusia harus membesarkan dan merawat salah satu dari jenis ini.

2. Binatang yang mati secara mendadak harus mendapatkan upacara perkabungan dengan dikuburkan dengan penghormatan sama seperti yang diberikan pada anggota suku.

3. Larangan memakan binatang kadang-kadang hanya ditujukan pada salah satu bagian tubuhnya saja.

4. Jika ada kebutuhan mendesak, biasanya diizinkan untuk membunuh binatang tersebut, tetapi hal ini dilakukan dengan meminta izin dari bianatang tersebut dan harus dilakukan tindakan-tindakan untuk menetralkan pelanggaran tabu (pembunuhan itu) dengan berbagai tipuan dan penghindaran.

5. Jika binatang itu dikorbankan untuk suatu upacara, ia harus mendapatkan perkabungan yang khidmat.

6. Pada upacara-upacara tertentu, seperti upacara keagamaan, anggotaanggota suku mengenakan kulit binatang. Jika suku tersebut masih menganut totemisme, maka kulit itu dari binatang totem

7. Suku dan individu memakai nama totem.

8. Banyak suku menggunakan gambaran binatang untuk perisai lengan dan menghiasi senjata dengan gambar binatang itu; lakilaki menggambari atau mentato tubuhnya dengan gambar binatang (totem) tersebut.

9. Jika binatang totem tersebut adalah binatang yang ditakuti dan berbahaya, maka mereka beranggapan bahwa anggotaanggota suku yang bernama sama dengannya tidak akan mendapatkan bahaya darinya.

10. Binatang totem melindungi dan memberi peringatan pada anggotaanggota suku.

11. Binatang totem memberikan ramalan masa depan untuk orang 
yang percaya padanya dan menjadi pemimpin suku tersebut.

12. Para anggota suatu suku totem seringkali percaya bahwa mereka memiliki asal-usul yang sama dengan binatang totem tersebut (S. Reinach dalam Freud, 2002: 163164).

Berdasarkan pada duabelas pernyataan tersebut dapat dipahami, bahwa pada hakikatnya binatang merupakan makhluk yang hendaknya dijaga dan dihormati. Kemudian selain agama totem, agama Hindu juga mengajarkan sikap saling mengasihi antar sesama makhluk hidup dan termasuk hewan di dalamnya. Kemudian untuk menyikapi pernyataan Freud yang menyatakan semua agama dan bentuk ritual merupakan perwujudan dari oedipus complex hingga melahirkan totem dan tabu, dapat diluruskan dengan penjelasan beberapa śloka Bhagavadgītā yang akan dijabarkan dalam sub-bab berikut.

\section{a) Pelaksanaan Yajña Berawal dari Wahyu Tuhan}

\begin{tabular}{lr}
\multicolumn{2}{c}{ Penjelasan mengenai } \\
permasalahan Oedipus complex \\
dari Freud yang esensinya
\end{tabular} menyatakan bahwa (totem dan tabu) terlahir dari permasalahan masa lalu, dirasakan kurang tepat. Di mana pada hakikatnya pernyataan tersebut dapat dibantah dan diluruskan dalam pandangan Ketuhanan Hindu dengan pedoman kitab suci Bhagavadgītā sebagai berikut:

śrī bhagavān uvāca: imaì vivasvate yogam proktavān aham avyayam, Vivasvān manave prāha manur ikșvākave 'bravīt

(Bhagavadgītā, IV. 1).

Terjemahannya:

Śrī Bhagawān bersabda: Ajaran yang abadi ini aku turunkan kepada Visvasvān, Visvasvān mengajarkan kepada Manu, dan Manu menerangkannya kepada Ikṣvaku (Pudja, 2013: 106).

Lebih lanjut petunjuk bagi yang ragu dalam memahami keEsaan Tuhan, dapat diluruskan dalam Bhagavadgītā (IV. 40) sebagai berikut:

Ajnas casraddadhanas ca samsayatma vinasyati, Nayam loko 'sti na paro na sukham samsayatmanah

(Bhagavadgītā, IV. 40)

Terjemahannya:

Tetapi mereka yang dungu dan tidak percaya dan bersifat ragu, akan hancur binasa, baginya tak ada kebahagiaan, tak ada dunia ini, demikian juga tak ada dunia sana (Pudja, 2013: 131).

Berdasarkan pernyataan śloka Bhagavadgītā, di atas dijelaskan bahwa, suatu ajaran yang tua ini (agama) diajarkan oleh Tuhan kepada para pengikutnya yang setia. Totem (kurban) dan tabu (aturan) muncul bukan karena ketakutan, tetapi sebagai rasa syukur manusia kepada Tuhan. Bhagavadgītā menegaskan bahwa Yajña (persembahan suci berupa totem) dilakukan bukan karena kesalahpahaman atau karena orang 
beragama mengidap oedipus complex seperti analisa Freud. Pelaksanaan suatu upacara dalam bentuk (totem), bukan semata-mata karena diawali dari masalah dosa masa lalu (tabu), melainkan karena sikap penghargaan dalam wujud cinta pada Tuhan. Hal ini diwujudkan dalam kesetiaan, pengabdian dan sikap meyakini ajaran kebenaran yang diturukan oleh yang maha kuasa. Menjalankan Yajña sebagai bentuk pengabdian kepada Tuhan, akan mengantarkan orang menuju kepada kebahagiaan. Namun demikian, terdapat orangorang yang bersifat ragu pada keEsaan Tuhan (seperti halnya Sigmund Freud). Tuhan tidak mengutuknya, ataupun membencinya, tetapi keraguan tersebut dengan sendirinya akan mengantarkan seseorang pada kecemasan, ketidakpuasan pikiran maupun batin, dan berujung pada ketidakbahagiaan. Namun, ketika orang-orang yang ragu maupun orang yang taat mampu memahami esensi yang sebenarnya mengapa melakukan persembahan suci, maka tidak akan ada yang melakukan dosa dan tidak ada penebusan dosa lagi.

Menyikapi masalah analisa Freud yang menyatakan bahwa orang beragama mengidap oedipus complex dapat dijawab dengan dasar śloka ini. Di mana ketika seseorang telah lupa akan dirinya maka akan melakukan dosa. Berbuat dan tidak tahu arah kemana harus menuju hingga tersesat. Hal tersebutlah yang mengakibatkan seseorang dapat gelap mata. Seperti yang di lakukan tokoh Oedipus yang tanpa sengaja membunuh ayahnya dan ingin menikahi ibunya. Sampai pada akhirnya melaksanakan upacara penebusan dosa melalui persembahan totem, dan mulai saat itu pula menikahi orang tua sendiri dianggap tabu. Namun berdasarkan mitologi tersebut, perlu diingat bahwa perilaku dosa terjadi dikarenakan manusia masih diselubungi oleh awidya (ketidaktahuan), dan karena selubung ketidaktahuan itulah yang menyebabkan ada beberapa orang dapat tersesat di jalan kegelapan.

\section{b) Pelaksanaan Yajña Sebagai Wujud Rasa Syukur pada Tuhan}

Penjelasan mengenai masalah oedipus complex (totem dan tabu) dapat pula diluruskan dengan kutipan Bhagavadgītà (VII. 22) adapun kutipannya adalah sebagai berikut:

sa tayà úraddhayà yuktàs tasyàràdhanam ihate, labhate ca tataá kàmàn mayaiva vihitàn hi tàn (Bhagavadgītā, VII. 22).

Terjemahannya:

Berpegang teguh pada kepercayaan itu, mereka sibuk pada keyakinan wujud itu pula dan dari padanya mereka memperoleh yang diharapkan, yang sebenarnya hanya dikabulkan oleh-Ku (Pudja, 2013: 197).

Berdasarkan kutipan śloka di atas dinyatakan bahwa sesungguhnya 
sikap sebagai seorang umat beragama adalah mampu taat pada ajaran Tuhan. Freud menganggap agama diciptakan melalui rasa ketakutan seorang anak yang telah membunuh ayah kandungnya, melalui ritual penebusan yang bernama totem, dan aturan atau tabu. Praktik kurban (totem) dan aturan atau etika dalam kehidupan (tabu) dalam pandangan Hindu, yang dilaksanakan dengan kesungguhan dan ketulusan hati, pada akhirnya akan bermuara pada Tuhan. Kecemasan dan ketakutan akan segera hilang, dan digantikan dengan kebahagiaan melalui karunia Tuhan. Dengan demikian, totem dan tabu bukan lahir dari sebuah pelarian manusia dari ketakutan, tetapi muncul dari kebahagian batin manusia atas rasa syukur kepada Tuhan.

\section{c) Pelaksanaan Yajña Sebagai Penjaga Keharmonisan Dunia}

Bhagavadgìtā , IX. 15 dan 16 menjelaskan pula mengenai makna mengapa agama Hindu tetap melaksanakan totem dan tabu. Adapun penjabaran dalam kutipan tersebut adalah sebagai berikut:

jñàna-yajñena càpy anye
yajanto màm upàsate,
ekatvenar påthaktvena
bahudhà viúvato-mukham
(Bhagavadgītā, IX. 15).

Terjemahannya:

Namun, ada yang berkurban dengan persembahan ilmu pengetahuan, dan memuja$\mathrm{Ku}$, dengan berbagai cara sebagai Yang Tunggal, Yang
Terpisah, Yang Menyeluruh dan Yang Maha Ada disemua penjuru (Pudja, 2013: 232).

Lebih lanjut penjelasan bentuk persebahan suci sebagai perwujudan dari Tuhan itu sendiri, dijelaskan dalam Bhagavadgītā (IX. 16) sebagai berikut:

ahaý kratur ahaý Yajña á
svadhàham ahaý aû̂adham,
mantro 'ham aham evàjyam
aham agnir ahaý hutam

(Bhagavadgītā, IX. 16).

Terjemahannya:

Aku adalah persembahan kratuh (kurban persembahan sebelum zaman veda), Aku adalah kurban (sesajian), Aku adalah sesajen kepada para leluhur (svadhā), Aku adalah bahan ramuan obat, Aku adalah mantra, Aku juga adalah mertega murni, Aku adalah api dan Aku adalah persembahan (huta) (Pudja, 2013: 232).

Berdasarkan kutipan Bhagavadgītā di atas, dijelaskan bahwa dalam penggunaan simbol (totem) misalnya, pelaksanaannya dapat dikategorikan dalam dua bentuk, yakni dalam bentuk non material dan material. Pelaksanaan yang diwujudkan dalam bentuk non material dapat disimbolkan melalui pikiran. Pengertian ini dimaksudkan untuk menggunakan ilmu pengetahuan sebagai wujud persembahan kepada Tuhan yang bersifat Saguna Brahman (Tuhan yang berwujud) maupun Nirguna Brahman (Tuhan yang tidak terdefinisikan). 
Wujud materiil (totem) dapat diwujudkan dalam bentuk persembahan berupa kratuh, kurban, sesajen pada leluhur, ramuan obat, mantra, mentega murni, api, dan persembahan (huta). Kesemua bentuk persembahan tersebut, semuanya berasal dari esensi Tuhan di dalamnnya. Dengan demikian, pemujaan manifestasi Tuhan dalam Hindu tidaklah tanpa alasan yang logis. Tuhan sebagai pencipta alam tidak jauh dari diri manusia, melainkan Tuhan merupakan bagian yang menyatu dengan setiap ciptaannya. Dengan alasan tersebut, sudah sepatutnya segala wujud persembahan, baik berupa persembahan ilmu pengetahuan maupun hasil dari alam semesta dipersembahkan kembali pada yang menciptakan. Dalam bentuk totem dengan didasarkan pada kesungguhan, ketulusan, dan keikhlasan.

\section{d) Pelaksanaan Yajña Sebagai Kewajiban}

Petunjuk melaksanakan

Yajña juga dijelaskan dalam kutipan Bhagavadgītā (XVII. 11) sebagai berikut:

aphalàkàòkûibhir yajño vidhidåûbo ya ijyate, yaûbavyam eveti manaá samàdhàya sa sàttvikaá (Bhagavadgītā, XVII. 11).

Terjemahannya:

Yajña menurut petunjuk kitabkitab suci, yang dilakukan oleh orang tanpa mengharap pahala dan percaya sepenuhnya bahwa upacara ini sebagai tugas kewajiban, adalah sàttvika (Pudja, 2013: 392).

Pelaksanaan Yajña dilaksanakan berdasarkan aturan yang jelas. Bhagavadgītā (XVII. 11) menegaskan bahwa kebijaksanaan dalam pelaksanaan Yajña (sāttvika Yajña) dapat ditentukan dari pelaksanaannya yang dilandasi oleh etika seseorang yang berpegang pada aturan kitab suci. Dengan tetap percaya bahwa melaksanakan Yajña (persembahan suci) merupakan suatu kewajiban bukan paksaan. Di mana hidup di dunia bukan hanya berbicara masalah hak apa yang di dapat dari alam, namun kembali pada kewajiban apa yang bisa diberikan pada alam dan juga sang pencipta Tuhan itu sendiri.

\section{e) Bentuk Kebijaksanaan Manusia Terletak dari Caranya BerYajña}

Penjelasan mengenai kebijaksanaan dalam melaksanakan Yajña dijelaskan dalam Bhagavadgītā (XVIII: 5) sebagai berikut:

Yajña -dàna-tapaá-karma na tyàjyaý kàryam eva tat, yajño dànaý tapaú caiva pàvanàni manîuióàm (Bhagavadgītā, XVIII. 5).

Terjemahannya:

Kegiatan berkurban, bersedekah dan tapa, jangan diabaikan melainkan harus dilakukan sebab Yajña, sedekah dan tapa brata adalah pensuci bagi orang 
arif bijaksana (Pudja, 2013: 405).

Berdasarkan pada penjelasan śloka di atas dapat ditarik sebuah kesimpulan bahwa pelaksanaan suatu Yajña (persembahan suci) menurut pandangan Hindu, merupakan sesuatu yang mampu memberikan fibrasi positif bagi yang melaksanakan. Yajña dapat memberi penyucian bagi orang yang melaksanakan dan mempersembahkanya. Selain itu, pelaksanaan kurban, bersedekah, dan tapa hendakanya dapat tetap dilaksanakan. Dengan landasan ketulusan dan keikhlasan serta disesuaikan dengan kemampuan. Berdasarkan hal tersebut, psikoanalisa agama dalam bentuk totem dan tabu dari Freud dapat diluruskan, dan umat beragama Hindu dengan tegas menolak jika konsep pemujaan menggunakan simbol (totem) dan etika (tabu) dikategorikan Freud muncul dari peristiwa oedipus complex.

\section{SIMPULAN}

Sigmund Freud yang merupakan tokoh psikoanalisis, menyusun kerangka pemikirannya mengenai agama berdasarkan latar belakang kehidupannya serta keterkaitannya dengan kisah mitologi. Analisis psikoanalisa Sigmund Freud terhadap agama dimulai dari pemikirannya yang kritis dalam menanggapi permasalahan sosial khususnya agama. Freud menganalisa agama dari segi keilmuannya, dan berusaha keluar dari keyakinan pribadinya. Dalam hal ini sifat keobjektifannya terkadang menimbulkan persoalan- persoalan, karena bertabrakan dengan nilai-nilai atau kepercayaan masyarakat yang dianggap suci. Freud sesungguhnya menganalisis agama bukan dalam tataran esensi, tetapi lebih kepada lapisan kulit luar yang diperlihatkan oleh agama.

Freud melalui psikoanalisa agamanya menyatakan bahwa penganut agama merupakan manusia-manusia yang sakit, seperti oedipus complex. Kisah oedipus compelx memang ditemukan dalam mitologi Watugung masyarakat Hindu di Bali.

\section{DAFTAR PUSTAKA}

Bagus, Lorenz. 2000. Kamus Filsafat. Jakarta: PT. Gramedia Pustaka Utama.

Baker, Rachel. 2007. Sigmund Freud Di Seberang Masa Lalu. Terjemahan oleh Jimmi Firdaus. Yogyakarta: Sketsa.

Barakatu, Abdul Rahman. 2007. "Kritik Terhadap Pandangan Sigmund Freud Agama dan Implikasinya terhadap Pendidikan". Jurnal Lentera Pendidikan. Vol 10. No.2. (Online). http://ejurnal.uin-alauddin.ac.id. Di akses pada Kamis 26 Juni 2020, Pukul13.25 Wita.

Donder, I Ketut. 2006. Brahmavidya: Teologi Kasih Semesta. Surabaya: Paramita.

Freud, Sigmund. 2002. Totem dan Tabu. Terjemahan oleh Kurniawan Adi Saputro. Yogyakarta: Jendela.

Freud, Sigmund. 2009. Pengantar Umum Psikoanalisis Sigmund Freud. Terjemahan oleh Haris Setiowati. Yogyakarta: Pustaka Pelajar. 
Pals, Daniel L. 2011. Seven Theories of Religion. Terjemahan oleh Inyiak Ridwan Muzir dan M. Syukri. Yogyakarta: IRCiSoD.

Pudja, Gede. 2013. Bhagavadgītā (Pañcama Veda). Surabaya: Paramita.

Scharfenberg, Joachim. 2003. Sigmund Freud Pemikiran dan Kritik Agama. Terjemahan oleh Shohifullah dkk. Yogyakarta: AK Group 